\title{
Farm monitoring as an initiator of improved farm management practices
}

\section{A.F. WATTERS}

Livestock Improvement, P.O. Box 75, Longburn, Palmerston North

\begin{abstract}
The Taranaki Agricultural Research Station (TARS) has produced $52 \%$ more milkfat/ha than the average Hawera farm through the 1980s. Respective stocking rates (3.7 vs 2.8 cows/ha) are the major reason for this production difference. Very little improvement in relative performance has been made over the decade. Monitoring projects in South Taranaki during 1988-89 and 1989-90 have shown that adopting a monitoring programme can result in increased production. The quantitative information collected provides farmers with the information and confidence to make major changes in their farming system. Dairy farmers need to monitor their own farms themselves. The programme chosen should be simple so that it can become incorporated into the farming routine. A simple method of monitoring is described that is based on recording pre- and post-grazing levels on 2-4 selected paddocks. Research and extension organisations need to adopt a number of recommendations if farm monitoring is to be taken up by the majority of dairy farmers: pasture assessment methods need to be standardised; production of a simple monitoring handbook for farmers; the publication of regular comaprative data from dairy companies and research organisations; and the commercial production of predictive computer-models.
\end{abstract}

K eywords monitoring, stocking rates, decisions

\section{Introduction}

Large production differences between the Taranaki Agricultural Research Station (TARS) and local Hawera farmers have been evident throughout the 1980s. This "production gap" does not seem to have narrowed as the decade has progressed.

This paper suggested that many farmers have a poor understanding of the basic input-output relationships involved on their farms. However, simple monitoring systems can provide farmers with the information and confidence to make the changes necessary to increase production.

\section{The comparison}

Dairy research facilities like TARS have been producing 600-800 kg milkfat (MF)/ha/yr at high stocking rates $(3.7$ cows/ha) for many years. Average production at TARS has been $52 \%$ higher than for the average Hawera farm throughout the 1980s. Regular field days and popular press articles (Thomson 1987) have extended these results and farming methods to the local farming community. The message from Bryant $(1977,1984)$ that the correct stocking rate and calving date for the farm and farming high quality cows are the keys to optimal performance, has been stressed by Dairy Board consulting officers during the 1980s. (7 discussion groups operated in the area involving approximately $70 \%$ of farms.)

Despite all this, the average Hawera farmer has not grasped the impact of higher stocking rates on increasing production -and--profitability. Table. 1 illustrates the slow progress made between $1981 / 2-1983 / 4$ and 1986/7-1988/9.

Though Hawera farmers have improved the conversion rate of dry matter to milkfat, this has been due largely to lower annual pasture production.

Table 1 Comparison of production trends at TARS and for average Hawera farmers

\begin{tabular}{lcc}
\hline & $1982 / 82-1983 / 841986 / 87-1989 / 89$ \\
\cline { 2 - 3 } Tonnes DM/ha/yr & 13.8 & 12.3 \\
\hline HAWERA COUNTY & & \\
Stocking rate & & 2.88 \\
(Cows/ha) & 2.73 & 428 \\
Milkfat (kg /ha) & 428 & 28.7 \\
$\begin{array}{l}\text { Conversion } \\
\text { (kg DM/kg MF) }\end{array}$ & 32.2 & \\
\cline { 2 - 2 } & & 3.7 \\
TARsing Rate & 3.7 & 596 \\
(Cows/ha) & 680 & 20.6 \\
Milkfat (kg/ha) & & \\
Conversion & 20.3 & \\
(kg DM/kg MF) & &
\end{tabular}

1 Rate of growth recorded at TARS 
Their low stocking rates at the end of the decade mean they are poorly placed to take advantage of more normal growth rate years.

Disaster has resulted for some farmers that have increased stocking rates. There seems to be a lack of understanding of the input-output relationships involved, with critical pasture cover and feeding level targets often ignored. The result has been low per cow production, high cow wastage rates and spread calving patterns.

Farm monitoring will help reduce these errors of judgement (Ridler \& Hurley 1984) by providing farmers with:

- an appreciation of the input/output

- relationship operating on farms

- an emphasis on forward planning

- increased confidence in decision making

- better control of the farming system through changing climatic conditions.

\section{Monitoring to facilitate decision making}

The methods of farm monitoring must be chosen to suit the end user. These will vary in complexity and time input according to the components of the farm system. However monitoring needs to be more quantitative than the informal monitoring system used by many farmers. Farmers often base their decisions on the vat, how "happy" the cows are and the view from a motorbike ridden down the race. While some are very good at making day to day decisions this way, there is little information collected to make strategic longer term decisions like setting stocking rates and calving dates.

Farm monitoring projects have been running in South Taranaki for the dairy farm season of 1988-89 and 1989-90. The monitoring programme adopted and summarised in Figure 1 aims at finding the constraints to profitable production.

Figure 1 The monitoring programme outline for the South Taranaki monitoring and focus farms

\begin{tabular}{|c|c|}
\hline Daily & $\begin{array}{l}\text { Record rainfall, } 10 \mathrm{~cm} \text { soil } \\
\text { temperature and maintain grazing } \\
\text { record }\end{array}$ \\
\hline Fortnightly & $\begin{array}{l}\text { Score pasture to provide: } \\
\text { - average farm cover, } \\
\text { - pasture growth rates, } \\
\text { - a measure of the level of feeding } \\
\text { for the herd } \\
\text { - a paddock Production Index, } \\
\text { similar to Livestock } \\
\text { Improvements' cow PI, } \\
\text { ranking paddocks on growth } \\
\text { rate performance }\end{array}$ \\
\hline Monthly & $\begin{array}{l}\text { Determine cow condition by scoring } \\
\text { indicator cows ( } 10 \% \text { of the herd) }\end{array}$ \\
\hline When required & $\begin{array}{l}\text { Monitor herd health, individual cow } \\
\text { performance, mating progress, } \\
\text { milking machine performance, soil } \\
\text { fertility and replacement liveweights }\end{array}$ \\
\hline
\end{tabular}

The 1988-89 monitoring project involved an above-average farmer, unsure of where further gains in production could be achieved. A major finding was that cow feed requirements were in excess of pasture growth (Watters 1989). To increase production from $500 \mathrm{~kg}$ MF/ha and $145 \mathrm{~kg} \mathrm{MF} / \mathrm{cow}$, the stocking rate needed to be dropped from 3.6 cows/ha to $3.3 \mathrm{cows} / \mathrm{ha}$. As a result of this option being taken, production increased to $620 \mathrm{~kg} \mathrm{MF} / \mathrm{ha}$ and $187 \mathrm{~kg} \mathrm{MF} / \mathrm{cow}$. After adjusting for fewer calves reared and fewer heifers in the herd during 1989-90 production is estimated to have improved by $23 \%$ compared with the district's $16 \%$ increase.

Monitoring provided the information and confidence to make an effective change to the farming system.

A similar monitoring programme was run for two focus farms in South Taranaki during the 1989-90 season, which highlighted areas for improvement on both farms. For the Glenn Rd focus farm, pasture growth rates and average pasture cover information indicated that the start of calving could shift from $20 / 7$ to $10 / 7$ while increasing stocking rate from 2.8 cows/ha to 3.4 cows/ha. The theoretical increase in production is in excess of $100 \mathrm{~kg} \mathrm{MF} / \mathrm{ha}$. Without the assurance of the monitoring information, the required changes may have taken 3-5 years to implement on the two focus farms.

\section{Simplifying monitoring}

Monitoring will help most farmers make strategic or long-term decisions. However, if the method of monitoring is too labour intensive or onerous, it may not get done! The alternative of choosing just one parameter to monitor, such as pasture cover, provides some valuable benchmarks. But it doesn't really help with those long term decisions of "how many cows should I milk?" or, "should I be calving later or earlier!". The following is a simple pasture monitoring programme designed for farmer use.

Two to four paddocks are chosen on the farm which are representative of the different soil types, grazing patterns and so on. If necessary, the gate posts are painted to remind the farmer that for each grazing in that paddock, the pasture will be scored pre- and post-grazing. The required information can be kept in a notebook, with scoring being done as part of the normal farming routine.

Over a season, a monthly record of average pasture cover, herd feeding levels, pre- and postgrazing levels and growth rates will be built up. The mathematics is simple and there is no requirement for expensive computer equipment.

(a) Average farm cover for the month can be estimated by summing and averaging the pre- and post-grazing scores for the monitoring paddocks. This technique is an extension of Piggot's (1986) work on measuring average farm cover. The farm's average cover can be compared with targets set by Bryant (1990) or with local research or focal farms. 
(b) Herd feed intakes can be assessed by dividing the apparent feed eaten per hectare by the cows grazing per hectare. Tables are readily available that compare feed intake with production.

(c) Pre- and post-grazing levels are measured directly and can be averaged for the month. These levels provide a measure to judge grazing management.

(d) Growth rates can be measured from the difference between the latest pre-grazing score and the last post-grazing score. Over a number of years information is built up that will help set the optimum stocking rate and calving date for the farm. The variation in pasture growth due to "good" or "poor" years can be adjusted back to an average by comparing soil temperature and rainfall information collected with local Met. station data.

A range of other information is useful in diagnosing the constraints to production. If the dairy company doesn't already provide the service, milksolids production needs to be graphed to show trends, Rainfall needs to be recorded daily - soil temperature at least weekly. Cow condition can be monitored by scoring the first and last row at milking on a monthly basis. The normal soil testing and herd testing records all add to the information about the farming system.

\section{Changing research and extension emphasis}

For monitoring to be successful in assisting New Zealand dairy farmers to increase production, a number of recommendations need to be effected:

\section{A standardiiation of dry matter assessment method in New Zealand to allow comparison between districts.}

The recommendations made by L'Huillier et al. (1988) to adopt "universal" calibrations for pasture probes and rising plate meters needs to be accepted by the scientific community.

\section{The production of a monitoring handbook for} farmers

A well written handbook with a number of contributors can effectively cover simple methods of monitoring, recording and interpreting results. This would serve to provide support to those farmers without an academic background and encourage the full use of monitoring information.

\section{Development of comparative information} sources

All dairy companies need to provide milk solids production comparisons with monthly statements TARS produces a monthly newsletter that provides research and monitoring data. Though fixed targets are useful, a newsletter provides farmers with a useful comparison with a system that is undergoing similar climatic constraints.

\section{Commercial production of interactive optimum} computer models that are useful on farm

A range of useful predictive pasture growth programs do exist (Baars et a/ 1977), but these need to become commercially available. Linear programs can run on standard computer hardware, and userfriendly programs that model farming systems nked to be developed in the near future.

\section{Summary}

The production gap between average farmers and TARS has remained large through the 1980s. Farmers need to monitor their farms in order to give them the confidence and information necessary to make the decisions required to increase production.

Monitoring systems have been shown to be successful in increasing production. However, for these systems to be relevant for dairy farmers, monitoring must be quick to undertake and simple to understand.

Research and extension needs to emphasise the methods and benefits of monitoring systems. Adoption of the following recommendations would help make monitoring more relevant or New Zealand dairy farmers:

- The standardisation of pasture assessment methods

- The production of a monitoring handbook

- The provision of more comparative data from research institutions and dairy companies,

- Computer models need to be commercially released.

\section{ACKNOWLEDGEMENTS}

I would like to thank the staff at TARS for their help in preparing information for inclusion in this paper.

\section{REFERENCES}

Baars, J.A.; Rollo, M.D. 1987. Predictive use of a pasture production model on commercial farms: some examples. Proceedings of the NZ Society of Animal Production 47: 39-56.

Bryant, A.M. 1997. Increasing production by better nutrition. Massey Dairy Farmers Conference Proceedings 39: 5 I-56.

Bryant, A.M. 1984. Feed and management strategies at Ruakura. Proceedings of the Ruakura Farmers Conference 36: 20-24.

Bryant, A.M. 1990. Optimum stocking and feed manaeement nractices. Proceedings of the $\mathbf{R}$ uakura Farmers' Conference 41: In press.

L'Hullier, P.J.; Thomson, N.A. 1988. Estimation of herbage mass in rye-grass/white clover dairy pastures. Proceedings of NZ Grassland Association 49: I 17-122.

Piggot, G.J. 1986. Methods for estimating pasture dry matter on dairy farms in Northland. Proceedings of NZ G rassland Association 47: 243-247.

Ridler, B.J.; Hurley, E.M. 1984. The management policy for Massey University's large herd. Procee'dings of the Ruakura Farmers Conference 36: 15-19.

Thomson, N.A. 1987. Is managemenl secondary? Dails News.

Walters, A.F. 1989. Monitoring for increased production and profit. 1989 Massey Dairy Furming Ammal 41: 161-165. 